\title{
Assessment of financial health of Slovak family businesses using models predicting financial distress
}

\author{
Mária Trúchliková1,* \\ ${ }^{1}$ University of Economics in Bratislava, Faculty of Business Management, Department of Business \\ Economy, Dolnozemská cesta1, 85235 Bratislava, Slovak republic
}

\begin{abstract}
The financial health of a company can be seen as the ability to maintain a balance against changing conditions in the environment and companies should pay more attention to the financial viability and risk management. There many models for predicting of financial problems of the companies, especially Altman, Ohlson or Zmijewski are the most cited ones. The main objective of the article is the review and assessment of the level of financial health of Slovak family business in selected industries. The data was obtained from Finstat database and financial statements from 2017, 2018 and 2019 were analysed. For assessing the financial health of selected family businesses 3 models predicting financial distress were used: Kralicek Quick Test, Taffler model and Virág-Hajdu model. The results show how many family businesses are facing to the financial problems using different types of predicting models.
\end{abstract}

\section{Introduction}

Financial viability is the one of the key issues for every enterprise, because current economic environment shaped by globalization, quick economic changes and fierce competition impose challenging conditions for businesses and their prosperity. That's the reason, why predicting corporate bankruptcy is a crucial task for modern risk management. Different models and approaches predicting corporate financial distress or viability can be classified as a specific tool of financial analysis. The paper focuses on the analysis of financial health in family businesses using selected prediction models.

\section{Comparison of Prediction Models}

The financial distress of business entities is closely connected with unpleasant consequences, and these are the main motivation factors for managers or financial analysts to search for the methods that can predict possible financial problems or bankruptcy in advance [1]. A number of models to detect financial distress have been developed in the past. In the literature of bankruptcy prediction, the models of Altman [2], Ohlson [3] and

* Corresponding author: maria.truchlikova@euba.sk 
Zmijewski [4] are the most cited ones that are based on accounting variables [5]. The pioneers of the empirical approach are Beaver [6] and Altman [2]. Beaver was one of the first researchers to study the prediction of bankruptcy using financial statement data. Beaver [6,7] found that a number of indicators could discriminate between matched samples of failed and non-failed firms for as long as five years prior to failure. The single dimensional model is different from reality, when the financial situation of company is seen as one unit, which cannot be evaluated only according one rate index [8]. Tamari [9] created so-called risk index model that presents very simple point system, including various rate indexes, which are generally accepted as indexes of the financial health of the company [8]. The breakthrough success was achieved by the world-famous multivariate DA model of Altman [2]. He considered simultaneous impact of several indicators on the financial condition of the company by combining them into a single measure (Z-score) [10]. Altman develop a five-factor model applying the linear discriminant analysis. The model was originally developed for publicly traded manufacturing enterprises and later was extended to unlisted manufacturing companies and to other models including non-manufacturing companies [11]. Ohlson [3] proposed a new model based on logit analysis with a set of nine accounting ratios [12] and was the first who used the method of logistic regression for creating the model to predict the probability of a company failure [7]. In 1978 was developed Springate model, that uses the ratio of multiple discriminant analysis. To determine the ratios anywhere that can detect the possibility of bankruptcy, Springate use multiple discriminant analysis to choose 4 ratios of 19 financial ratios were popular in the literature, which was able to distinguish between sound business insolvent and bankrupt [13]. Zmijewski [4] employed probit analysis and developed a three-variable distress prediction model. He used financial ratio analysis that measures the performance of debt or leverage and liquidity of a company. In his analysis, Zmijewski used probit analysis as applied to 40 companies in a state of bankruptcy and 800 companies that are still operating at the time, and then develop a model by using ROA, leverage, and liquidity ratios [14].

Table 1. Prediction accuracy of models

\begin{tabular}{|c|c|c|}
\hline Model & $\begin{array}{c}\text { Analysis } \\
\text { techniques }\end{array}$ & Description \\
\hline $\begin{array}{l}\text { Altman model } \\
\text { (Z-score) }\end{array}$ & $\begin{array}{l}\text { Multiple } \\
\text { Discriminant } \\
\text { Analysis }\end{array}$ & $\begin{array}{c}\text { Working capital/Total assets } \\
\text { Retained earnings/Total assets } \\
\text { Earnings before interest \& taxes/Total assets } \\
\text { Market value of equity/Book value of total liabilities } \\
\text { Sales/Total assets }\end{array}$ \\
\hline Taffler model & $\begin{array}{l}\text { Multiple } \\
\text { Discriminant } \\
\text { Analysis }\end{array}$ & $\begin{array}{c}\text { Earnings before taxes/short-term liabilities } \\
\text { Current assets/total liabilities } \\
\text { Short-term liabilities/total assets } \\
\text { Asset turnover (sales over assets). }\end{array}$ \\
\hline Spingate model & $\begin{array}{c}\text { Multiple } \\
\text { Discriminant } \\
\text { Analysis }\end{array}$ & $\begin{array}{c}\text { Working capital/total assets } \\
\text { Earnings before interest and taxes/total assets } \\
\text { Profit before tax/current liabilities } \\
\text { Sales/total assets }\end{array}$ \\
\hline Virág-Hajdu & $\begin{array}{l}\text { Discriminant } \\
\text { Analysis, Logit }\end{array}$ & $\begin{array}{c}\text { Quick liquidity ratio } \\
\text { Return on sales } \\
\text { Cash flow /Total debts } \\
\text { Current assets /Total assets } \\
\text { Acc. Receivable/Acc. payable } \\
\end{array}$ \\
\hline $\begin{array}{l}\text { Ohlson model } \\
\text { (O-Score) }\end{array}$ & Logit & $\begin{array}{c}\text { Log (Total assets/GNP price-level index) } \\
\text { Total liabilities/Total assets. } \\
\text { Working capital/Total assets } \\
\text { Current liabilities/Current assets. }\end{array}$ \\
\hline
\end{tabular}




\begin{tabular}{|c|c|c|}
\hline & $\begin{array}{r}\text { One if total liabilities exceed total assets, zero otherwise } \\
\text { Net income/Total assets } \\
\text { Funds provided by operations/Total liabilities } \\
\text { One if net income was negative for the last two years, } \\
\text { zero otherwise } \\
\text { NIt-NIt_1//NIt|+|NIt_1| where NIt and NIt_1 is the net } \\
\text { income for the most recent and the } \\
\text { preceding year respectively. The variable measures the } \\
\text { change in net income. }\end{array}$ \\
\hline $\begin{array}{c}\text { Zmijewski } \\
\text { (Probit model) }\end{array}$ & Probit & $\begin{array}{c}\text { Net income/Total assets } \\
\text { Total liabilities/Total assets } \\
\text { Current assets/Current liabilities }\end{array}$ \\
\hline
\end{tabular}

Source: own processing

There are many other models used to detect financial distress. In Czech Republic the first attempt at developing a national bankruptcy risk assessment model was made by Neumaiers in 1995 (so-called IN95 model) [15]. In the following years, the same authors, having a larger sample of companies, built other national models-IN99, IN01 and IN05 [9]. In Hungary Virág and Hajdu [16] created an early warning bankruptcy model family in 1996 indicating bankruptcy dangers for different sectors and branches of the economy using DA, based on the financial data of 10,000 economic units [17]. The most commonly model used in Germany, Switzerland and Austria is Kralicek Quick test. Peter Kralicek developed a model on a sample of companies from German-speaking countries. The Kralicek Quick Test includes both dynamic and static indicators [18]. In Slovakia, there are also several representatives focusing on prediction models. Chrastinová (CH-index) and Gurčík (G-index) were the first who applied the methodology of financial health prediction in agricultural companies $[10,19,20]$.

\subsection{Family firms and financial distress}

Family businesses are described as firms that are managed or controlled by founding families. The topic that often discussed in the literature is whether a family business has a better performance than a non-family business, so that they do not experience financial distress. Several studies addressing the issues of the determinants of a firm's financial distress, or family firms' performance refer to Agency Theory, which asserts that the separation of ownership and control results in conflicts of interest and asymmetric information between owners and managers [21]. The other problem is that family businesses intend to keep the control of the firm within their family. Some studies on family firms' capital structure point out that family firms are risk averse, pursue stability and avoid risky investment strategies. As a matter of fact, families are "risk willing", in terms of performance hazard, in order to maintain a firm's control and preserve the nonfinancial returns they derive from the business, but, at the same time, they are averse to entrepreneurial risk $[21,22]$. Characteristics of family owned companies could be a possible reason for family business risk aversion and the choice of capital structure [23].

\section{Methodology and data}

The data was obtained from Finstat database. This database contains financial data about all subjects with a registered ID in the Slovak Republic. We analysed financial situation of 
family businesses in manufacturing (SK NACE 20-Manufacture of chemicals and chemical products, 21-Manufacture of basic pharmaceutical products and pharmaceutical preparations, 22- Manufacture of rubber and plastic products, 23-Manufacture of other nonmetallic mineral products, 24- Manufacture of basic metals, 25- Manufacture of fabricated metal products, except machinery and equipment, 26-Manufacture of computer, electronic and optical products, 27- Manufacture of electrical equipment, 28-Manufacture of machinery and equipment n.e.c., 29-Manufacture of motor vehicles, trailers and semitrailers). We analysed a sample of 50 family businesses in Slovakia. Financial statements from 2017, 2018 and 2019 were analysed. The analysis carried out was based on models predicting financial distress. Methods such as linear discriminant analysis and logistic regression belong to classical statistical methods applied in prediction of corporate default risk. For assessing the financial health of selected family businesses 3 models predicting financial distress were used: Kralicek Quick Test, Taffler model and Virág-Hajdu model.

Kralicek Quick Test evaluates the company's financial and revenue position. The following aspects of a company's position are then evaluated:

- Financial stability: $\left(\mathrm{X}_{1}+\mathrm{X}_{2}\right) / 2$

- Revenue position: $\left(\mathrm{X}_{3}+\mathrm{X}_{4}\right) / 2$

- Overall position: (Financial stability + Revenue position) / 2

The company can be assigned with points ranging from one to five. The less points the company is assigned, the better the financial prognosis of the company.

Table 2. Kralicek Quick Test indicators

\begin{tabular}{|c|c|c|c|c|c|}
\hline Indicator & $\begin{array}{c}\mathbf{1} \\
\text { Very good }\end{array}$ & $\begin{array}{c}\mathbf{2} \\
\text { Good }\end{array}$ & $\begin{array}{c}\mathbf{3} \\
\text { Average }\end{array}$ & $\begin{array}{c}\mathbf{4} \\
\text { Weak }\end{array}$ & $\begin{array}{c}\mathbf{5} \\
\text { Very weak }\end{array}$ \\
\hline Equity / Assets $\left(\mathrm{X}_{1}\right)$ & $>30 \%$ & $>20 \%$ & $>10 \%$ & $>0 \%$ & Negat. \\
\hline $\begin{array}{c}\text { (Liabilities + loans) / Operating } \\
\text { cash-flow }\left(\mathrm{X}_{2}\right)\end{array}$ & $<3$ & $<5$ & $<12$ & $>12$ & $>30$ \\
\hline \multicolumn{7}{|c|}{ Financial stability } \\
\hline EBIT/Assets $\left(\mathrm{X}_{3}\right)$ & $>15 \%$ & $>12 \%$ & $>8 \%$ & $>0 \%$ & Negat. \\
\hline Operating cash-flow / Sales $\left(\mathrm{X}_{4}\right)$ & $>10 \%$ & $>8 \%$ & $>5 \%$ & $>0 \%$ & Negat. \\
\hline \multicolumn{7}{|c|}{ Revenue position }
\end{tabular}

Source: own processing

The Taffler model is based on calculating the following score: $\mathrm{Z}=0.53 \mathrm{X}_{1}+0.13 \mathrm{X}_{2}+$ $0.18 \mathrm{X}_{3}+0.16 \mathrm{X}_{4}$

$\mathrm{X}_{1}$ : earnings before taxes (EBT) over short-term liabilities,

$\mathrm{X}_{2}$ : denotes current assets over total liabilities,

$\mathrm{X}_{3}$ : denotes short-term liabilities over total assets

$\mathrm{X}_{4}$ : asset turnover (sales over assets).

$\mathrm{Z}>0.3$ Companies with a lower probability of bankruptcy

$\mathrm{Z}<0.2$ Companies with a higher probability of bankruptcy

The Virág-Hajdu model is based on logistic regression.

$\mathrm{X}_{1}$ : Quick ratio

$\mathrm{X}_{2}$ : Return on sales

$\mathrm{X}_{3}$ : Cash-flow/ Total liabilities

$\mathrm{X}_{4}$ : Current assets ratio

$\mathrm{X}_{5}$ : Acc. receivable/ Acc. payable 
In the logistic regression model, the starting point should be the so-called "odds" ratio which is the ratio of success and failure probabilities. Taking the logarithm of odds, this measure is called logit. The equation of the logistic regression model:

$$
\ln (\text { odds })=\ln \left(\frac{\widehat{p}_{i}}{1-\widehat{p}_{i}}\right)=\beta_{0}+\beta_{1} X_{1}+\beta_{2} X_{2}+\ldots .+\beta_{n} X_{n}
$$

The model works with regression function:

$$
\widehat{p}=\frac{e^{z}}{1+e^{z}}=\frac{e^{\beta_{0}+\sum_{i=0}^{n}\left(\beta_{i} X_{i}\right)}}{1+e^{\beta_{0}+\Sigma_{i=0}^{n}\left(\beta_{i} X_{i}\right)}}
$$

Estimated parameter values of the logistic regression function are as follows: $b_{0}=$ $3.432, \mathrm{~b}_{1},=-10.32, \mathrm{~b}_{2}=0.01439, \mathrm{~b}_{3}=-4.438, \mathrm{~b}_{4}=-0.02992, \mathrm{~b}_{5}=8.17$.

The measurement of predictive performance is often based on the analysis of data in a confusion matrix. This matrix reports how the model classified the different fault categories compared to their actual classification (i.e., predicted versus observed). This is represented by four pieces of data:

- True Positive (TP): An item is predicted as faulty, and it is faulty

- False Positive (FP): An item is predicted as faulty, and it is not faulty

- True Negative (TN): An item is predicted as not faulty, and it is not faulty

- False Negative (FN): An item is predicted as not faulty, and it is faulty

If company has more than one creditor and the value of its liabilities exceeds the value of its assets (i.e., has negative equity) or is unable to pay at least two financial obligations to more than one creditor for 30 days after the due date. We approximated this fact by the variable Current Assets/Current Liabilities, determining the breakpoint of this indicator at level 1. Companies are at risk of bankruptcy if the solvency ratio is less than 0.06 in 2017, or less than 0.08 in 2018 (Act no. 513/1991 Coll.). We identified non-prosperous companies according to criteria: equity ratio (less than 0.06 and 0.08 ), liquidity ratio (less than 1) and loss of company.

We also calculated:

- Sensitivity, what is the proportion of actual positives which are correctly identified as such: TP / (TP + FN)

- Specificity, what is the proportion of negatives which are correctly identified as such: $\mathrm{TN} /(\mathrm{FP}+\mathrm{TN})$

- Accuracy: (TP+TN)/(TP+FP+FN+TN)

- Empirical Error I evaluatse the number of true positives which were classified as true negatives: FN/TP + FN

- Empirical Error II shows how many of true negatives were classified false positives: FP/FP +TN

Table 3. Confusion matrix

\begin{tabular}{|c|c|c|c|}
\hline \multicolumn{4}{|c|}{ Current category } \\
\hline \multirow{2}{*}{$\begin{array}{c}\text { Predicted } \\
\text { category }\end{array}$} & & $\mathrm{T}$ & $\mathrm{F}$ \\
\cline { 2 - 4 } & $\mathrm{T}$ & True positives (TP) & False positives (FP) \\
\cline { 2 - 4 } & $\mathrm{F}$ & False negatives (FN) & True negatives (TN) \\
\hline
\end{tabular}

Source: own processing 


\section{Results}

The models applied to assess the financial performance of family businesses in selected industries and reveal the risk of bankruptcy use different financial ratios as predictors. The models use together 13 financial-economic ratios. Table 3 presents their descriptive statistics - mean, median and standard deviation.

Table 4. Descriptive statistics of selected ratios

\begin{tabular}{lrrr}
\hline \multicolumn{1}{c}{ Financial-Economic Ratios } & Mean & Median & \multicolumn{1}{c}{ St. Deviation } \\
\hline Assets / Equity & 0,43 & 0,41 & 0,26 \\
(Liabilities + loans) / Operating cash & 104,08 & $-0,20$ & 1017,67 \\
EBIT/Assets & 0,10 & 0,07 & 0,13 \\
Operating cash-flow / Sales & $-0,28$ & 0,09 & 4,76 \\
Earnings before taxes (EBT) over short-term liabilities & 0,53 & 0,17 & 1,59 \\
Current assets over total liabilities & 3,43 & 1,04 & 14,45 \\
Short-term liabilities over total assets & 0,42 & 0,40 & 0,25 \\
Asset turnover & 1,62 & 1,33 & 1,27 \\
Quick ratio & 3,66 & 0,90 & 17,50 \\
Return on sales & $-35,20$ & 3,71 & 499,51 \\
Current assets ratio & 56,84 & 57,57 & 23,35 \\
Acc. receivable/ Acc. payable & 2,57 & 1,05 & 5,86 \\
Cash-flow/ Total liabilities & 0,52 & 0,22 & 1,18 \\
\hline
\end{tabular}

Source: own processing

Table 5. Descriptive statistics for Taffler model

\begin{tabular}{|c|c|c|c|c|c|c|c|c|}
\hline \multicolumn{9}{|c|}{ Taffler model } \\
\hline \multicolumn{3}{|c|}{2019} & \multicolumn{3}{|c|}{2018} & \multicolumn{3}{|c|}{2017} \\
\hline Mean & Median & St. Dev. & Mean & Median & $\begin{array}{c}\text { St. } \\
\text { Dev. }\end{array}$ & Mean & Median & St. Dev. \\
\hline 0.76 & 0.59 & 1.10 & 1.52 & 0.63 & 4.35 & 0.91 & 0.63 & 0.97 \\
\hline \multicolumn{9}{|c|}{$Z$ score } \\
\hline$Z<0.2$ & $(0,2 ; 0,3)$ & $Z>0.3$ & $Z<0.2$ & $(0,2 ; 0,3)$ & $Z>0.3$ & $Z<0.2$ & $(0,2 ; 0,3)$ & $Z>0.3$ \\
\hline 6 & 3 & 41 & 2 & 1 & 47 & 0 & 2 & 48 \\
\hline $\begin{array}{c}\text { higher } \\
\text { prob. of } \\
\text { bankr. }\end{array}$ & $\begin{array}{l}\text { Grey } \\
\text { zone }\end{array}$ & $\begin{array}{c}\text { lower } \\
\text { prob. of } \\
\text { bank. }\end{array}$ & $\begin{array}{c}\text { higher } \\
\text { prob. of } \\
\text { bank. }\end{array}$ & $\begin{array}{l}\text { Grey } \\
\text { zone }\end{array}$ & $\begin{array}{l}\text { lower } \\
\text { prob. } \\
\text { of } \\
\text { bank. }\end{array}$ & $\begin{array}{c}\text { higher } \\
\text { prob. of } \\
\text { bank. }\end{array}$ & $\begin{array}{l}\text { Grey } \\
\text { zone }\end{array}$ & $\begin{array}{c}\text { lower } \\
\text { prob. of } \\
\text { bank. }\end{array}$ \\
\hline
\end{tabular}

Source: own processing

Statistical characteristics, such as the mean, median, and stabdard deviation, were for each year. Table 5 shows an example of the results when applying the Taffler model for the companies with lower and higher probability of bankruptcy. This model and results will be compared with Kralicek Quick test and Virág-Hajdu model.

Table 6. Descriptive statistics for Kralicek Quick Test

\begin{tabular}{|c|c|c|c|c|c|c|c|c|}
\hline \multicolumn{9}{|c|}{ Kralicek Quick Test } \\
\hline \multicolumn{3}{|c|}{2019} & \multicolumn{3}{c|}{$\mathbf{2 0 1 8}$} & \multicolumn{3}{c|}{2017} \\
\hline Mean & Median & St. Dev. & Mean & Median & St. Dev. & Mean & Median & St. Dev. \\
\hline 2.45 & 2.38 & 0.96 & 2.31 & 2.25 & 0.89 & 2.30 & 2.25 & 0.76 \\
\hline \multicolumn{8}{|c|}{ Quick Test (points) } \\
\hline
\end{tabular}




\begin{tabular}{|c|c|c|c|c|c|c|c|c|}
\hline $\mathbf{1 - 4}$ & $\mathbf{4 - 5}$ & $\mathbf{5}$ & $\mathbf{1 - 4}$ & $\mathbf{4 - 5}$ & $\mathbf{5}$ & $\mathbf{1 - 4}$ & $\mathbf{4 - 5}$ & $\mathbf{5}$ \\
\hline 48 & 2 & 0 & 48 & 2 & 0 & 49 & 1 & 0 \\
\hline $\begin{array}{c}\text { Very } \\
\text { good- } \\
\text { weak }\end{array}$ & $\begin{array}{c}\text { Weak- } \\
\text { very } \\
\text { weak }\end{array}$ & $\begin{array}{c}\text { Very } \\
\text { weak }\end{array}$ & $\begin{array}{c}\text { Very } \\
\text { good- } \\
\text { weak }\end{array}$ & $\begin{array}{c}\text { Weak- } \\
\text { very } \\
\text { weak }\end{array}$ & $\begin{array}{c}\text { Very } \\
\text { weak }\end{array}$ & $\begin{array}{c}\text { Very } \\
\text { good- } \\
\text { weak }\end{array}$ & $\begin{array}{c}\text { Weak- } \\
\text { very weak }\end{array}$ & $\begin{array}{c}\text { Very } \\
\text { weak }\end{array}$ \\
\hline
\end{tabular}

Source: own processing

As it is clearly seen from the table 6 that represents the results of Kralicek Quick Test for years 2017-2019, only 2 ( 1 in 2017) companies are threatened by financial distress, because higher score implies the thread for the company, and lower score represents the financial stability of the company.

Table 7. Descriptive statistics for Virág - Hajdu model

\begin{tabular}{|c|c|c|c|c|c|c|c|c|}
\hline \multicolumn{9}{|c|}{ Virág-Hajdu model } \\
\hline \multicolumn{3}{|c|}{2019} & \multicolumn{3}{|c|}{2018} & \multicolumn{3}{|c|}{2017} \\
\hline Mean & Median & St. Dev. & Mean & Median & St. Dev. & Mean & Median & St. Dev. \\
\hline 0.58 & 0.74 & 0.45 & 0.59 & 0.87 & 0.45 & 0.55 & 0.80 & 0.45 \\
\hline \multicolumn{9}{|c|}{$\hat{p}_{\text {-value }}$} \\
\hline $\begin{array}{c}\hat{p}_{<} \\
0.525\end{array}$ & $\hat{p}_{\substack{>0.52 \\
5}}$ & Immeras. & $\begin{array}{c}\hat{p}_{<} \\
0.525\end{array}$ & $\begin{array}{c}\hat{p}_{>} \\
0.525\end{array}$ & Immeras. & $\begin{array}{c}\hat{p}_{<} \\
0.525\end{array}$ & $\hat{p}_{>0.525}$ & Immeras. \\
\hline 20 & 29 & 1 & 21 & 28 & 1 & 23 & 26 & 1 \\
\hline Prosper & Non-pr. & $X$ & Prosper & Non-pr. & $X$ & Prosper & Non-pr. & $X$ \\
\hline
\end{tabular}

Source: own processing

The results of Virág-Hajdu model are shown in Table 7. the function received as an outcome of the logistic regression resulted in a higher classification accuracy in the case of both groups. Virág - Hajdu discriminant analysis worked with the whole error of $22.10 \%$, their logistic regression function, on the other hand, affects the lower overall error only $18.20 \%$.

Table 8. Prosperous and non - prosperous companies

\begin{tabular}{|c|c|c|c|c|c|c|c|c|}
\hline \multicolumn{3}{|c|}{} & \multicolumn{3}{c|}{ Virág - Hajdu model } & \multicolumn{2}{c|}{ Kralicek Quick Test } \\
& $\begin{array}{c}\text { Non- } \\
\text { prosp. }\end{array}$ & Prosp. & & $\begin{array}{c}\text { Non- } \\
\text { prosp. }\end{array}$ & Prosp. & & $\begin{array}{c}\text { Non- } \\
\text { prosp. }\end{array}$ & Prosp. \\
\hline Non- & 6 & 17 & Non- & 23 & 0 & Non- & 2 & 21 \\
prosper. & 2 & 17 & prosper. & 19 & 2 & prosper. & 2 & 17 \\
$\mathbf{2 0 1 9}$ & 0 & 22 & $\mathbf{2 0 1 9}$ & 22 & 0 & $\mathbf{2 0 1 9}$ & 1 & 21 \\
$\mathbf{2 0 1 8}$ & & & $\mathbf{2 0 1 8}$ & & & $\mathbf{2 0 1 8}$ & & \\
$\mathbf{2 0 1 7}$ & & & $\mathbf{2 0 1 7}$ & & & $\mathbf{2 0 1 7}$ & & 27 \\
\hline Prosper. & 0 & 27 & Prosper. & 7 & 20 & Prosper. & 0 & 21 \\
$\mathbf{2 0 1 9}$ & 0 & 31 & $\mathbf{2 0 1 9}$ & 10 & 19 & $\mathbf{2 0 1 9}$ & 0 & 31 \\
$\mathbf{2 0 1 8}$ & 0 & 28 & $\mathbf{2 0 1 8}$ & 5 & 23 & $\mathbf{2 0 1 8}$ & 0 & 28 \\
$\mathbf{2 0 1 7}$ & & & $\mathbf{2 0 1 7}$ & & & $\mathbf{2 0 1 7}$ & & \\
\hline
\end{tabular}

Source: own processing

According to Taffler model more than 54\% (in 2019) and 62\% (in 2018) and 56\% (in 2017) of companies are prosperous and the rest of them are in financial troubles. According to Virág-Hajdu model more than 40\% (in 2019) and 38\% (in 2018) and 46\% (in 2017). According to Kralicek Quick test more than 54\% (in 2019) and 62\% (in 2018) and 56\% (in 2017). 
Table 9. Model's Comparison

\begin{tabular}{|l|c|c|c|c|c|c|c|c|c|}
\hline \multirow{2}{*}{ Model } & \multicolumn{3}{|c|}{2019} & \multicolumn{3}{c|}{2018} & \multicolumn{3}{c|}{2017} \\
\cline { 2 - 10 } & TM & VHM & KQT & TM & VHM & KQT & TM & VHM & KQT \\
\hline Sensit. & $100 \%$ & $74,1 \%$ & $100 \%$ & $100 \%$ & $65,5 \%$ & $100 \%$ & $100 \%$ & $82,1 \%$ & $100 \%$ \\
\hline Specif. & $26,1 \%$ & $100 \%$ & $8,7 \%$ & $10,5 \%$ & $90,5 \%$ & $10,5 \%$ & $0 \%$ & $100 \%$ & $4,5 \%$ \\
\hline Accur. & $66 \%$ & $86 \%$ & $58 \%$ & $68 \%$ & $76 \%$ & $66 \%$ & $56 \%$ & $90 \%$ & $58 \%$ \\
\hline $\begin{array}{l}\text { Type I } \\
\text { Err. }\end{array}$ & $0 \%$ & $25,9 \%$ & $0 \%$ & $0 \%$ & $34,5 \%$ & $0 \%$ & $0 \%$ & $17,9 \%$ & $0 \%$ \\
\hline $\begin{array}{l}\text { Type II } \\
\text { Err. }\end{array}$ & $73,9 \%$ & $0 \%$ & $91,3 \%$ & $89,5 \%$ & $9,5 \%$ & $89,5 \%$ & $100 \%$ & $0 \%$ & $95,5 \%$ \\
\hline
\end{tabular}

TM- Taffler model, VHM - Virág-Hajdu model, KQT- Králicek Quick Test, Sensit.- sensitivity, Specif.-specificity, Accur. - accuracy, Type I Err.- Type I Error, Type II Err. - Type II Error.

Source: own processing

The comparison is based on working with terms as Type I Error and Type II Error. Results of models' comparison are including in table 9. The value of Type I Error is $0 \%$ in the case of Taffler model and Kralicek Quick Test, 2,59\% in the case of logistic regression - Virág Hajdu model. The value of Type II Error is higher than the value of Type I Error for all models except Virág Hajdu model. It means that models predicting financial distress have difficulties to classify safe business entities correctly. The models with high prediction ability are generally connected with the statement that the value of errors cannot exceed 20$25 \%$.

\section{Discussion}

Our research showed that it is possible to predict financial distress in the family businesses in selected industry. For assessing the financial health of selected family businesses 3 models predicting financial distress were used: Kralicek Quick Test, Taffler model and Virág-Hajdu model. The Taffler model is based on calculating $\mathrm{Z}$ score and it is one the most cited model, Kralicek Quick Test which evaluates the company's financial and revenue position and company can be assigned with points ranging from one to five. The last one was Virág-Hajdu model based on logistic regression. Financial measures represented by Virág-Hajdu model have a good explanatory power (according to Type II Error). Prediction models contain a combination of indicators, including their weights suitable for evaluating the performance and credibility of the company. Determining the prosperity od the company and diagnose the financial health of the company should be one of the key issues of the company.

It is necessary to emphasize that the models predicting corporate financial distress should provide quick and inexpensive recommendations. On the one hand they can help in decision making and strategy creation but on the other hand they should not be used as the only tool and they work with limitations.

This paper is the output of the internal grant project of the University of Economics in Bratislava (Faculty of Business Management) no. I-21-109-11-00 called "Research of Family Businesses in Context of Sustainable Development” (100\%). 


\section{References}

1. E. Gregova, K. Valaskova, P. Adamako, M. Tumpach, J. Jaros, Predicting Financial Distress of Slovak Enterprises: Comparison of Selected Traditional and Learning Algorithms Methods. Sustainability, 12, (2020)

2. E. I. Altman, Edward, Financial Ratios, Discriminant Analysis and the Prediction of Corporate Bankruptcy. Journal of Finance, 23, 589-609 (1968)

3. J.A. Ohlson, Financial Ratios and the Probabilistic Prediction of Bankruptcy. Journal of Accounting Research, 18, 109-31 (1980)

4. M. E. Zmijewski, M.E., Methodological Issue Related to The Estimation of Financial Distress Prediction Models. Journal of Accounting Research, 22, 59-82 (1983)

5. N. Bărbuță-Mișu, M. Madaleno, Assessment of Bankruptcy Risk of Large Companies: European Countries Evolution Analysis. Journal of Risk and Financial Management, 13, (2020).

6. W. H. Beaver, Financial Ratios as Predictors of Failure. Journal of Accounting Research, 4, 71-111 (1966)

7. L. Svabova, L. Michalkova, M. Durica, E. Nica, Business Failure Prediction for Slovak Small and Medium-Sized Companies. Sustainability, 12 (2020)

8. A. Csikosova, M. Janoskova, K. Culkova, Limitation of Financial Health Prediction in Companies from Post-Communist Countries. Journal of Risk and Financial Management, 12, (2019).

9. M. Tamari, Financial ratios as a means of forecasting bankruptcy. Management International Review, 6, 15-21 (1966)

10. B. Prusak, Review of research into enterprise bankruptcy prediction in selected central and eastern European countries. International Journal of Financial Studies, 6, 60-88 (2018)

11. L. Lesáková, P. Gundová, M. Vinczeová, The practice of use of models predicting financial distress in Slovak companies. Journal of Eastern European and Central Asian Research, 7, 123-136 (2020)

12. S. Ashraf, E.G. S. Félix, Z. Serrasqueiro, Do Traditional Financial Distress Prediction Models Predict the Early Warning Signs of Financial Distress? Journal of Risk and Financial Management, 12, (2019).

13. Sinarti, T.M. Sembiring, Bankruptcy Prediction Analysis of Manufacturing Companies Listed in Indonesia Stock Exchange. International Journal of Economics and Financial Issues, 5, 354-359 (2015)

14. M. Fakhri Husein, Galuh Tri Pambekti, Precision of the models of Altman, Springate, Zmijewski, and Grover for predicting the financial distress. Journal of Economics, Business, and Accountancy Ventura, 17, 405 - 416 (2014)

15. O. Machek, Long-term Predictive Ability of Bankruptcy Models in the Czech Republic: Evidence from 2007-2012. Central European Business Review, 3, 14-17 (2014)

16. O. Hajdu, Ottó, M. Virág, Hungarian Model for Predicting Financial Bankruptcy. Society and Economy in Central and Eastern Europe, 23, 28-46 (2001)

17. T. Kristóf, M. Virág, A Comprehensive Review of Corporate Bankruptcy Prediction in Hungary. Journal of Risk and Financial Management, 13, (2020).

18. M. Situm, Analysis of correlation behavior of solvent and inslovent firms based on accounting ratios. Journal of Modern Accounting and Auditing, 11, 233-259 (2015) 
19. M. Bod'a, V. Úradníček, Predicting Financial Distress of Slovak Agricultural Enterprises. Ekonomický časopis, 67, 426-452 (2019).

20. K. Valaskova, P. Durana, P. Adamko, J. Jaros, Financial Compass for Slovak Enterprises: Modeling Economic Stability of Agricultural Entities. Sustainability, 13, (2020)

21. P. Gottardo, A.M. Moisello, Family forms, Risk-taking and financial distress. Problems and Perspectives in Management, 15, 168-177 (2017)

22. L. R. Gómez-Mejía, K.T .Haynes, M. Núñez-Nickel, K. J. Jacobson, J. MoyanoFuentes, Socioemotional wealth and business risks in family-controlled firms: Evidence from Spanish olive oil mills. Administrative science quarterly, 52, 106-137 (2007)

23. L. A. Tabot Ntoung, H. M. Santos de Oliveira, B. M. Ferreira de Sousa, L. Marques Pimentel, S. A. Moreira Carvalho Bastos, Are Family Firms Financially Healthier Than Non-Family Firm? Journal of Risk and Financial Management, 13, (2020). 